and monitor progress and analyze their strategies over time through a continuous adaptive management process.

$$
* * *
$$

1. Ermakova, E. P. «Zelenaya finansovaya strategiya» Velikobritanii 2019 g. - programmnyj dokument v oblasti «zelenogo» finansirovaniya // Obrazovanie i pravo. - 2020. - №9.

2. Savinskij, S. P. Stanovlenie i razvitie «zelenogo» kreditovaniya v KNR // Ekonomicheskie issledovaniya. $-2019$.

3. Semenova, N. N., Eremina O. I., Skvorcova M. A. «Zelenoe» finansirovanie v Rossii: sovremennoe sostoyanie i perspektivy razvitiya // Finansy: teoriya i praktika. - 2020.

4. Fedorova, E. P. Rol' gosudarstva v reshenii problem razvitiya «Zelenogo» finansirovaniya // Finansovyj zhurnal. - 2020. - №4.

5. Oficial'nyj sajt VEB. RF // URL: https://veb.ru/ustojchivoe-razvitie/zeljonoe-finansirovanie/ (data obrashcheniya: 04.06.2021)

6. Oficial'nyj sajt Garant.ru // URL: https://www.garant.ru/products/ipo/prime/doc/72137248/ (data obrashcheniya: 04.06.2021)

7. Oficial'nyj sajt Ministerstva finansov Rossii // URL: https://minfin.gov.ru/ru/document/?id_4=122805razrabotka_predlozhenii_podderzhivayushchikh_dyeyatelnost_po_vystraivaniyu_tselostnoi_sistemy_mer _i_mekhanizmov_razvitiya_i_gosudarstvennoi_podderzhki_zelenogo_finansirovaniy

(data obrashcheniya: 03.06.2021)

8. Oficial'nyj sajt Pravitel'stva RF // URL: http://government.ru/info/35569/ (data obrashcheniya: 04.06.2021)

9. Oficial'nyj sajt TASS // URL: https://tass.ru/ekonomika/6999512 (data obrashcheniya: 04.06.2021)

10. Oficial'nyj sajt Central'nogo banka RF // URL: https://cbr.ru/Content/Document/File/84163/press_04102019.pdf (data obrashcheniya: 05.06.2021)

\title{
Semagina A.S., Shulikov A.O. \\ Prospects for the development of a public-private partnership in the fisheries management complex of the Kamchatka Krai
}

doi $10.18411 / g q-31-07-2021-14$

Kamchatka State Technical University (Russia, Petropavlovsk-Kamchatsky)

\section{Abstract}

The article discusses the main provisions of legislation in the field of public-private partnership in the Russian Federation and identifies the main factors influencing its development, and an analysis of the activities of the fisheries complex of the Kamchatka Krai was carried out in 2020; An evaluation was made of the effectiveness of the implementation of State programmes in the fisheries management complex of Kamchatka Krai, proposals were made for the development of public-private partnerships in the fisheries sector of the region, and an assessment was made of corruption risks.

Keywords: Kamchatka Krai, fisheries management complex, aquaculture, publicprivate partnership.

Various models of public-private partnerships in various spheres of human activity are widespread throughout the world now. For Russia, public-private partnership (hereinafter PPP) is a relatively new mechanism for economic development, the role of which will increase with development and adaptation.

The formation of institutions for interaction between the State and business in the current conditions is an essential factor for effective and sustainable economic and social development, both at the federal and regional levels. In view of the needing to improve the competitiveness of efforts to improve the quality of life of the population, there is a needing for a new economic model based on private initiative and State regulation of economic processes. One of the proven tools for achieving these goals is the use of public-private 
partnerships that can ensure a long-term transition at all levels of interaction to balanced social, environmental and economic development.

The development of PPP is determined by several major factors that influence the expansion of the scope and form of interaction between government and business (Antonova K. A. 2011).

Firstly, PPP is one of the mechanisms of a mixed economy that allows the development of business-state relations.

Secondly, PPP involves private sector resources in reproductive processes in government- and local-government-owned industries and areas, and uses private business initiative to improve budget spending.

Thirdly, combining the efforts and resources of business and the State in the framework of specific projects creates their additional competitive advantages. Business has greater flexibility and adaptability than public institutions, faster decision-making, ability to innovate, and a desire to seek technological and technological improvements to ensure competitiveness. The State, in turn, can ensure the more successful implementation of PPP projects by establishing a stable legal framework, organizing activities, including interaction with civil society, and using financial resources-economic instruments: material support, subsidies, financial guarantees, preferential taxation and other forms of support.

In 2016, the Federal Law «On Public-Private Partnership, Municipal-Private Partnership in the Russian Federation and Amending Individual Legal Acts of the Russian Federation» entered into force, the purpose of which is «Creation of legal conditions for attracting investments in the economy of the Russian Federation and improvement of the quality of goods, works and services, the organization of which consumers are the responsibility of the bodies of state power and bodies of local self-government». (Government of the Russian Federation 2015).

We will focus on the regional aspects of the establishment of a PPP mechanism, using the example of the Kamchatka Krai Fisheries Management Complex (FMC). On the basis of the current version of the Act, we will specify the key principles for the implementation of PPPs - the pooling of resources and the allocation of risks of the parties to the agreement, attracting private investment into the economy and ensuring that State and local authorities have access to goods, work and services and improve their quality.

Thus, creating an enabling environment for PPPs:

- To strengthen the activities of the FMC members by stimulating various forms of partnership in the Kamchatka region;

- To expand the scope of application of PPP in line with government strategic documents;

- To develop the market for PPP projects by stimulating offers from domestic and foreign investors;

- To form and develop «points of growth» around regional FMC, involving in realization of projects unused resources of other subjects.

As a result, this should unleash the untapped potential of PPP projects to address the challenges of the region's FMC transition to sustainable development.

The development of the FMC of Kamchatka Krai takes place against the backdrop of numerous constraints, primarily infrastructure. In this connection, in order to improve the interaction between the State and business structures in the FMC of Kamchatka Krai, the use of PPP mechanisms in the format of territories leading development (TLD) can be considered. This instrument is based on the principle of partnership between the State and business. In accordance with the TLD Act, the State provides the infrastructure necessary for residents. This instrument thus makes the financial model of the project attractive to the investor in a context of limited budgetary means. (Government of the Russian Federation 2014).

In addition, the main obstacle to attracting investors is the lack of a realistic understanding of returns on the part of project proponents. The starting point for PPP-based 
fisheries development projects is the willingness of private investors to take on the public sector risks arising from the specific public, economic and social challenges they face. Therefore, structuring risks is an essential part of the PPP mechanism in implementing projects in the industry. A key factor in its low investment attractiveness for long-term investments is the high level of risk in the fisheries complex of Kamchatka Krai.

The fishing industry has traditionally been dominant in the economic life of the Kamchatka region. The state of the fisheries sector largely determines the direction and dynamics of many other sectors of the region's economy.

Kamchatka Krai continues to lead in production volumes. According to the results of 2020, Kamchatka fishermen extracted 1,530,000 tons (or 99\% of the total in 2019), which represents more than $40 \%$ of the catch in the Far East and more than $30 \%$ of the national catch.

The first in the catching structure is the mint, and the second is the Pacific salmon. Herring, flounder, navaga, cod, termug, halibut, iwais sardine, squid, crabs and other types of aquatic bioresources are also mined by enterprises of Kamchatka Krai.

There are currently more than 800 organizations operating in Kamchatka Krai (according to State registration data) that catch and (or) process aquatic biological resources with a year-round or seasonal production cycle.

Within the framework of the state program of the Kamchatka Krai «Development of the fishing complex of the Kamchatka Krai», approved by the Resolution of the Government of the Kamchatka Krai from 29.11.2013 533-Two investment projects were implemented to build and modernize fish processing complexes on the coasts of Kamchatka, which allowed to invest 2.4 billion roubles in the industry.

State support for the realization of investment projects is provided from the funds of the provincial budget in the form of subsidies for the reimbursement of a part of the costs of payment of interest on loans, advance payments and leasing payments.

During the period of operation of regional sectoral programmes from 2010 to 2020, support from the provincial budget amounted to 750 million roubles. Received 42 investment projects with a total of RUB 18 billion in extra-budgetary investments. (Ministry of Fisheries of the Kamchatka Territory n.d. 2020).

For the successful implementation of the projects, the sectoral organizations of Kamchatka Krai attract not only regional but also federal State support measures; according to the results of 2020, 14 fisheries organizations are residents of the territory of the leading social organizations-economic development of «Kamchatka», 8 investment projects on modernization of the fleet and construction of fish processing complexes were realized (the volume of capital investment on realized projects amounted to 6.6 billion rub.).

Implementation of the State support mechanism for attracting investment in the industry in the form of investment quotas for the construction of fishing fleets and fish processing plants continues.

Production (harvesting) quotas of aquatic biological resources for fisheries investment for industrial fisheries and (or) coastal fisheries in 2020 allocated (and fully developed) A total of 34,000 tons for 6 enterprises in the fisheries complex of Kamchatka Krai.

Projects on construction of 5 fish processing plants (LLC «Kamchattralstrafstad», LLC «Vityaz-Auto», LLC «Ukinsky liman», LLC «Zarya», LLC «Fishing kolkhoz im. V.I. Lenin) were realized in territory of the Krai within the framework of investment quotas and projects on construction of 3 fish processing plants (LLC «Fish Canning Plant «Commander», LLC «KGB-Donka», LLC «Oktyabrsky-1») are realized.

Under the investment quotas of the Fisherman's collective farm named V.I. Lenin has already built 3 mid-trawlers-seiners. Another 17 fishing boats are under construction by Kamchatka enterprises. 
The effects of the investment quota programme include an increase in the investment activity of the enterprises participating in the programme, an increase in the projected tax return from the projects carried out and the creation of modern jobs.

Overall, between 2008 and 2020, enterprises in the fisheries complex invested more than 66 billion roubles in developing their coastal processing capacity and modernizing the fishing fleet. 29 modern plants were built on the coasts of the peninsula, 24 ships were built, acquired and modernized.

It should be noted that one of the problems in financing PPP projects is the lack of a common understanding of PPP implementation mechanisms in both business and government. To overcome this problem, the Kamchatka Krai Development Corporation was established in 2014 as part of the Kamchatka Krai Government, including one of the functions of the corporation was to prepare, launch and manage PPP projects. But during the period of operation of this corporation in the territory of the Kamchatka Krai, one PPP project which was not related to the fisheries complex was implemented.

In our view, the first task of the FMC public administration is to create conditions that will enable the State to derive maximum benefit from the operation of the aquatic biological resources.

The most attractive sector of the Kamchatka Region FMC in which PPPs can be effectively developed in our view is the area of aquaculture development.

At present, there are only five state fish-water-producing plants under the FSBI «Sevvestostrovod» operating on the territory of the province. This is due to the fact that aquaculture development in Kamchatka is currently not commercially efficient, and traditional commercial activities in the FMC are more cost-effective and generate significant cash flow.

The investment portfolio of JSC «Kamchatka Development Corporation» contains several projects related to the development of aquaculture. Among other things, creation of salmon fish-aquatic plants with the funds of private investors (pasture fish farming), construction of a floating complex for reproduction and transformation of Kamchatka crab by the basin method, creation of a mariculture farm «Vilyuchinskaya Bay». But not one of these projects has been able to attract investors. (Industrial parks and technoparks of Russia).

The main reasons why investors do not pay attention to aquaculture development projects in Kamchatka Krai are:

1. Lack of infrastructure on the peninsula coast (roads, transport, energy);

2. High cost of fuel, energy tariffs, utilities, relatively high labor and maintenance costs;

3. Significant logistical costs for the delivery of planting material, feed and final aquaculture products.

In our view, the establishment of the necessary infrastructure should be entrusted to the State, within the framework of PPP, which in the future will make it possible to attract both domestic and foreign investors to the development of the FMC of Kamchatka Krai in general, and in particular to the development of aquaculture projects.

In any case, however, the State must retain ownership of the project, since it is the State that is responsible for the development of infrastructure facilities and can be the subject of international policies and of the promotion of domestic enterprises in external markets.

As the current Russian experience shows, new types of corruption transactions are emerging within the framework of PPPs, consisting of solidarity between representatives of the State and a private partner in the use of budgetary resources on a non-market basis for the purpose of illegally obtaining income from both sides. The most important institutional condition for an effective PPP system is the symmetry between the interests of the State and those of private investors interested in attracting budgetary resources for the implementation of agreed projects. Since it is precisely the high transaction costs that can be incurred by an investor that are a reason to constrain the development of PPPs. In large public image 
projects, it is not always possible for a private partner to identify all the risks within the framework of its commitments. The scale and technical complexity of a project can cause serious problems for a private investor who does not have the same level of information as a State counterpart (Roj O M 2014).

$$
\text { *** }
$$

1. Antonova K. A. 2011 Theoretical foundations of public-private partnership. Vestnik universiteta. Moscow. GOU VPO «GUU». 22. - P. 132-134. (in Russian)

2. Government of the Russian Federation 2014 About territories advanced socio-economic development in Russian Federation (Federal Law 473-FZ, dated 29 dec. 2014) (Moscow, Russia)

3. Government of the Russian Federation 2015 About public-private partnership, municipal-private partnership in the Russian Federation and amendments to separate legislative acts Russian Federation (Federal Law 224-FZ, dated 13 Jul. 2015) (Moscow, Russia)

4. Industrial parks and technoparks of Russia. Development Corporation of Kamchatka announced measures to support the development of aquaculture in the region https://russiaindustrialpark.ru/news/korporaciyarazvitiya-kamchatki-obyavila-o-merah-podderzhki-razvitiya-akvakultury-v-krae

5. Ministry of Fisheries of the Kamchatka Territory n.d. The report on the activities of the Ministry of Fisheries of the Kamchatka Krai Available at https://minfish.kamgov.ru/otcet-o-deatelnostiministerstvarybnogo-hozajstva-kamcatskogo-kraa-za-2020-god

6. Roj O. M. Corruption risks in development of public-private partnership system in Russia. All-Russian scientific conference "current problems of scientific support of the state policy of the Russian Federation in the field of countering corruption" Yekaterinburg, June 25-27, 2014. P. 295-302 